\title{
KONSELING PADA IBU TENTANG IMUNISASI DPT
}

\author{
Yoan Marini \\ Program Studi DIII Kebidanan STIKES Mitra Adiguna Palembang. Komplek Kenten Permai Blok J No 9-12 \\ Bukit Sangkal Palembang 30114 \\ Email : yoan15marini@gmail.com
}

\begin{abstract}
Abstrak
Imunisasi DPT adalah suatu vaksin yang melindungi terhadap difteri, pertusis dan tetanus. Difteri desebabkan bakteri yang menyerang tenggorokan dan dapat menyebabkan komplikasi yang serius dan fatal .Penyakit ini mudah menular melalui batuk atau bersin. Pengetahuan ibu terhadap imunisasi merupakan faktor yang sangat penting, agar ibu dapat cepat tanggap dan tahu apa yang harus dilakukan ketika timbul efeksamping pada anaknya untuk mendapatkan cakupan kelengkapan imunisasi. TujuanPenelitian untuk mendeskripsikan semua teori-teori maupun jurnal yang berkaitan dengan konseling terhadap pengetahuan ibu tentang imunisasi DPT. Desain peneliti ini menggunakan studi literatur atau review. Sumber data penelitian ini menggunakan data sekunder yang di dapat dengan melakukan studi pustaka dari jurnal-jurnal yang sesuai dengan topik penelitian sebanyak 10 jurnal dan 2 buku. Hasil dan pembahasan berdasarkan hasil studi literatur yang didapatkan ada manfaat dan pengaruh konseling terhadap pengetahuan ibu tentang imunisasi DPT. Berdasarkan hasil yang dominan yaitu dimana pengetahuan sangat berperan penting agar ibu tau tentang apa itu imunisasi DPT dan mau mengajak anaknya untuk imunsasi. Dapat disimpulkan bahwa selama ini para ibu kurang mendapatkan informasi yang lengkap tentang imunisasi khususnya DPT, sehingga pengetahuan mereka tentang imunisasi DPT banyak yang kurang mengerti dari hasil literatur review dari 10 jurnal yang menyatakan hal yang sama bahwa konseling berpengaruh terhadap pengetahuan ibu. Saran untuk peneliti selanjutnya agar hasil peneliti dapat dijadikan sebagai landasan dalam upaya menindaklanjuti hasil penelitian yang ada kearah penelitian yang luas.
\end{abstract}

Kata Kunci : Konseling, imunisasi DPT

\begin{abstract}
DPT immunization is a vaccine that protects against diphtheria, pertussis and tetanus. Diphtheria is caused by bacteria that attack the throat and can cause serious and fatal complications. The disease is easily spread by coughing or sneezing. Mother's knowledge of immunization is a very important factor, so that mothers can respond quickly and know what to do when side effects arise on their children to get complete immunization coverage. The aim of this study is to describe all theories and journals related to counseling on maternal knowledge about DPT immunization. This research design using literature study or review. The data source of this research uses secondary data obtained by conducting literature studies from journals that are in accordance with the research topic as many as 10 journals and 2 books. Results and discussion based on the results of a literature study found that there were benefits and effects of counseling on maternal knowledge about DPT immunization. Based on the dominant result, knowledge plays an important role so that mothers know about DPT immunization and want to invite their children for immunization. It can be concluded that so far mothers have not received complete information about immunization, especially DPT, so that their knowledge of DPT immunization is not clear from the results of literature reviews from 10 journals which state the same thing that counseling affects maternal knowledge. Suggestions for future researchers so that the results of the researchers can be used as a basis in an effort to follow up existing research results towards broad research.
\end{abstract}

Keywords : Counseling, DPT immunization 


\section{PENDAHULUAN}

Imunisasi merupakan upaya pemerintah untuk mencapai Milennium Development Goals (MDGs) yang salah satu tujuannya adalah untuk menurunkan angka kematian anak. Angka kematian bayi merupakan indikator utama yang digunakan untuk menentukan derajat kesehatan masyarakat baik ditingkat provinsi maupun nasional. Berdasarkan kondisi tersebut, program-program di Indonesia menitik beratkan pada upaya penurunan angka kematian bayi melalui imunisasi, sebab anak merupakan investasi masa depan (Melisa, dkk 2016).

Imunisasi DPT adalah suatu vaksin yang melindungi terhadap difteri, pertusis dan tetanus. Difteri desebabkan bakteri yang menyerang tenggorokan dan dapat menyebabkan komplikasi yang serius dan fatal. Penyakit ini mudah menular melalui batuk atau bersin. Pertusis (batuk rejan) adalah infeksi bakteri pada saluran udara yang ditandai dengan batuk hebat yang menetap serta bunyi pernafasan yang melengking. Pertussis juga dapat menimbulkan komplikasi serius, seperti pneumonia, kejang dan kerusakan otak. Tetanus adalah infeksi bakteri yang bisa menyebabkan kekakuan pada rahang serta kejang. Vaksin ini diberi 5 kali pada usia 2,4,6,18 bulan dan 5 tahun (Marimbi, 2010).

Pengetahuan ibu terhadap imunisasi merupakan faktor yang sangat penting, agar ibu dapat cepat tanggap dan tahu apa yang harus dilakukan ketika timbul efek samping pada anaknya untuk mendapatkan cakupan kelengkapan imunisasi. Kurangnya pengetahuan orang tua terutama ibu akan membawa sikap negative dan rasa takut akan efek samping imunisasi yang nantinya akan berdampak pada pandangan ibu dan kemauan ibu untuk membawa anaknya ke fasilitas kesehatan guna mendapatkan imunisasi. Sehingga ada ibu yang berpandangan bahwa imunisasi akan menjadi hal yang merugikan pada anaknya (Safitri, 2019).

Konseling merupakan pendekatan komunikasi interpersonal yang sering digunakan dalam peningkatan pengetahuan dan perubahan sikap serta prilaku dalam bidang kesehatan (Azzahra dan Muniroh, 2015).

Data WHO (World Health Organization) mengenai persentase populasi target yang divaksinasi adalah vaksin BCG (89\%), diikuti dengan DPT 1 (90\%), DPT 3 (86\%), Hep-B (84\%), Hib 3 (72\%), dan imunisasi Polio 3 (85\%) (WHO, 2018).

Berdasarkan hasil Survei Demografi Kesehatan Indonesia (SDKI) tahun 2017 jenis imunisasi yang cakupannya tertinggi adalah vaksin BGC dan polio 1 (91\%), diikuti dengan vaksin DPT-HB/DPT-HBHib pertama dan polio 2 (89\%). Cakupan DPT-HB/DPT-HB-Hib dan polio selanjutnya lebih rendah. Cakupan terendah adalah pada vaksin polio $4(72 \%)$. Enam persen anak umur 12-23 bulan sama sekali tidak menerima imunisasi (SDKI, 2017).

Berdasarkan data kasus Difteri menyebar hampir semua wilayah di Indonesia. Jumlah kasus Difteri pada tahun 2018 sebanyak 1.386 kasus, jumlah kematian sebanyak 29 kasus, dengan CFR sebesar 2,09\%. Jumlah kasus Difteri tahun 2018 meningkat drastis hampir 2 kali lipat dibandingkan tahun $2017 \quad$ (954 kasus)proporsi kasus Difteri menurut Provinsi di Indonesia Sumatera Selatan termasuk ke-8 besar kasus Difteri terbanyak yaitu 61,11\% (Profil Kesehatan RI, 2018).

Data Kementerian Kesehatan menunjukkan bahwa sampai dengan bulan November 2017, kasus Difteri dilaporkan 
dari 95 Kabupaten /Kota yang terletak di 20 Provinsi di Indonesia. Ada 11 Provinsi yang melaporkan terjadinya KLB Difteri di wilayah kabupaten/Kota-nya selama bulan Oktober dan November 2017, yaitu Sumatera Barat, Jawa Tengah, Aceh, Sumatera Selatan, Sulawesi Selatan, Kalimantan Timur, Riau, Banten, DKI, Jawa Barat dan Jawa Timur (Madon, 2017).

Berdasarkan hasil penelitian Gusti (2017) yang berjudul pengaruh promosi kesehatan menggunakan metode konseling terhadap pengetahuan ibu hamil tentang imunisasi dasar anak di wilayah kerja Puskesmas Nanggalo Padang. Didapatkan hasil bahwa terjadi peningkatan nilai mean rank setelah diberikan konseling, nilai mean rank sebelum konseling 15,79 dan setelah di berikan konseling 18,93 serta didapat nilai $\mathrm{p}=0,000 \quad(<0,05)$ maka dapat disimpulkan ada pengaruh promosi kesehatan terhadap peningkatan pengetahuan ibu hamil tentang imunisasi dasar.

Berdasarkan hasil penelitian Kusuma (2019) yang berjudul gambaran pengetahuan dan sikap orang tua dalam pencegahan difteri di Desa Walitelon Utara, Temanggung. Menunjukkan bahwa sebagian besar pengetahuan orang tua berdasarkan tingkat pendidikan dasar baik yaitu 17 orang $(41,5 \%)$. Pengetahuan orang tua berdasarkan tingkat pendidikan menegah baik yaitu sebanyak 36 orang $(63,3 \%)$. Pengetahuan orang tua berdasarkan tingkat pendidikan tinggi baik sebanyak 4 orang (100\%). Pengetahuan orang tua berdasarkan tingkat pekerjaan baik sebanyak 36 orang $(70,6 \%)$ bekerja dan 21 orang $(53,8 \%)$ tidak bekerja. Sikap orang tua dalam pencegahan difteri baik sebanyak 75 orang $(83,3 \%)$, kurang baik sebanyak 11 orang $(12,2 \%)$ dan tidak baik sebanyak 4 orang $(4,4 \%)$.

Berdasarkan hasil penelitian Sa'diah, dkk (2018) yang berjudul gambaran pengetahuan orang tua, dukungan keluarga, dan status imunisasi terhadap kejadian difteri pada balita di wilayah Puskesmas Cileungsi Kabupaten Bogor tahun 2018. Jumlah sampel sebanyak 10 orang dan data diperoleh dengan wawancara mendalam hasil yang diperoleh bahwa yang menyebabkan terjadinya difteri di Wilayah Puskesmas Cileungsi karena kurangnya pengetahuan orang tua, dukungan keluarga terhadap jadwal pemberian imunisasi dan manfaat imunisasi serta ada satu kelompok yang menolak untuk imunisasi karena hal tersebut mengandung barang yang haram. Berdasarkan penelitian yang dilakukan diperoleh kesimpulan bahwa pengetahuan, dukungan keluarga dan status imunisasi memiliki pengaruh terhadap kejadian difteri. Untuk itu, diharapkan Puskesmas setempat memberikan jonseling dan pendekatan pada masyarakat yang masih menolak imunisasi, memberikan edukasi dengan cara penyuluhan serta memberikan penghargaan bagi orangtua yang memberikan imunisasi DPT lengkap sesuai jadwalnya.

Berdasarkan studi pendahuluan yang peneliti lakukan dari hasil pembagian kuesioner kepada 10 responden tentang pengetahuan mereka seputar imunisasi DPT diberikan 15 soal tentang imunisasi DPT, setelah selesai di isi kuesioner diambil dan dihitung jumlah benar dan salah dengan hasil ukur baik jika responden menjawab $\geq$ $50 \%$ dan hasil ukur kurang $\leq 50 \%$, didapatkan 3 orang menjawab benar lebih dari 8 soal $(\geq 50 \%)$, dan 7 orang menjawab benar kurang dari 7 soal $(\leq 50 \%)$ tentang imunisasi DPT.

Dari data diatas maka peneliti menggunakan studi pustaka untuk mengetahui konseling pengetahuan ibu tentang imunisasi DPT. Studi pustaka adalah suatu studi yang tujuannya untuk memperoleh dukungan teoritis terhadap masalah penelitian yang dipilih, maka peneliti perlu banyak membaca buku, baik berupa buku teks (teori) maupun hasil penelitian orang lain, majalah, dan sebagainya (Notoatmodjo, 2010)

Dalam melakukan studi literatur ada beberapa teknik yang digunakan antara lain, mengupas atau mengkritik (critize), membandingkan (compare), meringkas (summarize), mengumpulkan (synthesize), 
dan bertentangan (contrast). Dan penulis menggunakan metode compare, yaitu Konseling Pada Ibu Tentang Imunisasi DPT.

\section{METODE PENELITIAN}

Fokus penelitian ini menggunakan literatur review yaitu serangkaian penelitian yang berkenaan dengan metode pengumpulan data pustaka atau penelitian yang objek penelitiannya digali melalui berbagai informasi kepustakaan (buku, ensiklopedia, jurnal ilmiah, koran, majalah dan dokumen). Studi literatur bisa didapat dari berbagai sumber baik jurnal, buku, dokumentasi, internet dan pustaka. Metode studi literatur adalah serangkaian kegiatan yang berkenaan dengan metode pengumpulan data pustaka, membaca dan mencatat, serta mengelola bahan penulisan (Zed, 2008 dalam Nursalam 2016).

\section{Jenis Penelitian}

Jenis penulisan yang digunakan adalah studi literatur review yang berfokus pada hasil penelitian yang berkaitan dengan topik atau veraiabel penulisan. Pada penelitian ini peneliti mengumpulkan semua kepustakaan yang dipublikasikan berkaitan dengan penerapan konseling pada ibu tentang imunisasi DPT.

\section{Waktu Penelitian}

Waktu penelitian ini dilakukan pada bulan November 2020 s.d selesai.

\section{HASIL PENELITIAN DAN PEMBAHASAN}

Hasil penelitian studi literatur ini disajikan secara naratif untuk menggambarkan hasil penelitian dari 10 Artikel / hasil penelitian yang Relevan. Dengan topik / masalah analisis konseling pada ibu tentang imunisasi dpt.

Berdasarkan penelitian Arifin dan Prasasti (2017), Faktor Yang Berhubungan Dengan Kasus Difteri Anak Di Puskesmas Bangkalan.

Difteri pada umumnya lebih banyak menyerang pada usia anak 5-7 tahun. Penyakit infeksi angkut yang disebabkan oleh bakteri Corynebacterium diptheriae. Adapun tujuan penelitian adalah untuk mengetahui faktor yang berhubungan dengan kasus difteri anak. Penelitian ini menggunakan desain studi case control. Analisis univariat dilakukan guna melihat distribusi frekuensi masing-masing variabel yang diteliti dan analisis bivariat dilakukan guna mengetahui terdapat hubungan yang bermakna antara variabel bebas dan variabel terkait. Uji chi-square dengan melihat derajat kemaknaan hubungan apabila nilai $\mathrm{p}<0,05 \quad(\mathrm{p}<\alpha)$ yang artinya terdapat hubungan. Hasil penelitian menunjukan bahwa ada hubungan antara kelengkapan status imunisasi DPT dengan tingginya kasus difteri anak. Faktor paling dominan yang berhubungan dengan tingginya kasus difteri anak adalah status imunisasi DPT dengan nilai ( $\mathrm{p}$ value $=0,037, \mathrm{OR}=4,667$ ) Yang artinya responden dengan status imunisasi DPT tidak lengkap memiliki 5 kali lebih berisiko menderita difteri dibandingkan dengan responden dengan status imunisasi DPT lengkap. Saran petugas Puskesmas angkalan khususnya bidan desa hendaknya meningkatkan kerjasama dengan para kader kesehatan untuk meningkatkan perannya sebagai educator dan conselor dalam memberikan informasi berupa peningkatan frekuensi penyuluhan kepada masyarakat mengenai risiko penularan difteri akibat pemberian imunisasi DPT tidak lengkap serta manfaat pemberian imunisasi dasar pada anak keseluruh Desa di wilayah kerja Puskesmas Bangkalan pada kegiatan Posyandu hingga mencapai target desa UCI dapat terpenuhi.

\section{Berdasarkan penelitian Gusti} (2017), Pengaruh Promosi Kesehatan Menggunakan Metode Konseling terhadap Peningkatan Pengetahuan Ibu Hamil Tentang Imunisasi Dasar Anak Di Wilayah Kerja Puskesmas Nanggolo Padang.

Imunisasi melindungi anak terhadap beberapa Penyakit Yang Dapat Dicegah Dengan Imunisasi (PD3I) seorang anak yang diimunisasi dengan vaksin yang disuntikkan 
pada lokasi tertentu atau diteteskan melalui mulut sebagai salah satu kelompok yang menjadi sasaran program imunisasi, setiap bayi wajib mendapatkan imunisasi dasar lengkap yang terdiri dari 1 dosis $\mathrm{BCG}, 3$ dosis DPT-HB dan atau DPT-HB-Hib, 4 dosis polio, dan 1 dosis campak. Adapun tujuan penelitian ini adalah untuk mengetahui pengetahuan ibu hamil tentang imunisasi dasar anak. Jenis penelitian adalah quasi eksperiment dengan desain one group pretest-posttest design. Subyek dalam penelitian ini adalah $67 \mathrm{ibu}$ hamil menggunakan lembar balik dan konseling. Simpulan terdapat pengaruh konseling terhadap peningkatan pengetahuan ibu hamil tentang imunisasi dasar.

Berdasarkan penelitian Harahap, dkk (2019), Gambaran Pengetahuan Dan Motivasi Ibu Tentang Pemberian Imunisasi DPT Lanjutan (BOOSTER) di Puskesmas Simpang IV Sipin Kota Jambi.

Tingginya angka kejadian DPT membuat pemerintah untuk melakukan imunisasi DPT lanjutan (Booster), karena imunisasi DPT lanjutan (Booster) penting dilakukan dalam upaya mempertahankan tingkat kekebalan agar tetap tinggi sehingga dapat memberikan perlindungan yang optimal, maka pemeberian imunisasi pada seorang anak perlu ditambah dengan dosis DPT lanjutan (Booster) untuk meningkaykan kekebalannya yang diberikan pada usia 18 bulan. Perlindungan optimal dari pemberian imunisasi DPT lanjutan (Booster) ini hanya didapat apabila anak tersebut telah mendapat imunisasi dasar secara lengkap. Adapun tujuan penelitian untuk mengetahui Gambaran Pengetahuan Dan Motivasi Ibu Tentang Pemberian Imunisasi DPT Lanjutan (Booster). Penelitian ini merupakan penelitian kuantitatif yang bersifat deskriptif. Teknik pengumpulan sampel dilakukan dengan cara Accidental Sampling yaitu diperoleh $79 \mathrm{ibu}$ yang memiliki balita. Pengumpulan data dilakukan melalui pengisian kuesioner dengan analisis univariat. Dapat disimpulkan bahwa sebagian besar responden memiliki pengetahuan kurang sebanyak $44.3 \%$ sebagian responden memiliki motivasi tinggi sebanyak $50.6 \%$ dan sebagia besar balita tidak mendapatkan imunisasi DPT Lanjutan (Booster) sebanyak 82.3\%. Perlunya peningkatan promosi kesehatan kepada para ibu tentang pentingnya pemberian imunisasi DPT Lanjutan (Booster) yang dapat dilakukan seperti dengan mengadakan penyuluhan, kelas ibu balita, posyandu, konseling perorangan atau kelompok, pemasangan baliho, pembagian panplet dan pemasangan poster tentang imunisasi DPT Lanjutan (Bosster)sehingga mempermudah ibu balita untuk memperoleh informasi tentang imunisasi Lanjutan (Booster).

Berdasarkan penelitian Yuviska, dkk (2015), Hubungan Pengetahuan Ibu Tentang Efek Samping Imunisasi DPT Combo Dengan Kejadian Demam Pada Bayi Usia 2-12 Bulan Di BPS Yulianti Amd.Keb Kelurahan Talang Teluk Betung selatan Bandar Lampung.

Imunisasi DPT merupakan suatu upaya pemberian toksoid difteri, vaksin pertusis, dan toksoid tetanus yang bertujuan untuk menimbulkan kekebalan aktif terhadap penyakit difteri, pertusis, dan tetanus dalam waktu yang bersamaan. Adapun tujuan penelitian ini adalah untuk mengetahui hubungan pengetahuan ibu tentang efek samping imunisasi DPT Combo dengan kejadian demam pada bayi usia 2-12 bulan. Rancangan penelitian adalah cross sectional. Sampel 97 orang teknik sampling yang digunakan adalah Random Sampling. Uji statistik data menggunkan chi square. Simpulan diketahui sebagian besar pengetahuan ibu tentang efek samping imunisasi DPT Combo termasuk dalam kategori cukup yaitu sebanyak 38 orang $(39,2 \%)$. Kejadian demam pada bayi usia 212 bulan sebanyak 48 orang $(49,5 \%)$. Ada hubungan pengetahuan ibu tentang efek samping imunisasi DPT combo dengan kejadian demam pada bayi usia 2-12 bulan dengan $\mathrm{p}$-value $=0,000$. Saran, hasil 
penelitian ini dapat digunakan bagi institusi pelayanan kesehatan sebagai masukan dalam upaya peningkatan kesehatan terutama yang berhubungan dengan hubungan pengetahuan ibu tentang efek samping imunisasi DPT Combo dengan kejaidan demam pada bayi 2-12 bulan.

Berdasarkan penelitian Aprilia, dkk (2018), Hubungan Pengetahuan Dengan Sikap Ibu Tentang Imunisasi Difteri Pada Anak Balita Di Desa Jatiwates Kecamatan Tembelang Kabupaten Jombang.

Difteri adalah penyakit akibat terjangkit bakteri yang bersumber dari corynebacterium diphteriae. Penyakit ini merupakan penyakit mengerikan di mana masa lalu sering menyebabkan kematian dan sampai saat ini masih mewabah di negara yang belum berkembang. Orang yang selamat dari penyakit ini menderita kelumpuhan otot tertentu dan kerusakan permanen pada jantung dan ginjal. Anakanak yang berumur satu sampai sepuluh tahun sangat peka terhadap penyakit ini. Kuman difteri disebarkan oleh menghirup cairan dari mulut atau hidung orang yang terinfeksi, dari jari-jari atau handuk. Adapun tujuan penelitian untuk mengetahui hubungan pengetahuan dengan sikap ibu tentang imunisasi difteri. Penelitian yang digunakan adalah analitik korelasi. Sampel sebanyak 55 orang dengan dibagikan kuesioner. Hasil penelitian didapatkan didapatkan bahwa nilai rerata pengetahuan responden sebesar 13.29. Diketahui bahwa terdapat 24 responden $(83,3 \%) \mathrm{p}=0,007<$ 0,05 . Ada hubungan pengetahuan dengan sikap ibu tentang imunisasi difteri pada anak balita. Diharapkan meningkatkan penyuluhan tentang imunisasi difteri dan memberikan dorongan pada ibu tentang pentingnya mendapatkan imunisasi difteri.

4.1.8 Kusuma (2019), Gambaran Pengetahuan dan Sikap Orang Tua Dalam Pencegahan Difteri Di Desa Walitelon Utara Temanggung.

Penyakit menular semakin menunjukkan kenaikan jumlah misalnya saja penyakit difteri, orang tua mempunyai peranan penting dalam pencegahan penyakit. Adapun tujuan penelitian adalah untuk mengetahui gambaran pengetahuan dan sikap orang tua dalam pencegahan difteri. Penelitian ini menggunakan metode deskriptif dengan pendekatan cross sectional. Populasi penelitian sebanyak 903 kepala keluarga. Teknik sampling menggunakan proporsional rando sampling. Jumlah sampel 90 kepala keluarga. Pengumpulan data menggunakan kuesioner pengetahuan dan sikap difteri. Analisis data menggunakan distribusi frekuensi. Hasil penelitian menunjukkan bahwa sebagian besar pengetahuan orang tua berdasarkan tingkat pendidikan dasar baik yaitu 17 orang $(41,5 \%)$. Pengetahuan orang tua berdasarkan tingkat pendidikan menegah baik yaitu sebanyak 36 orang $(63,3 \%)$. Pengetahuan orang tua berdasarkan tingkat pendidikan tinggi baik sebanyak 4 orang (100\%). Pengetahuan orang tua berdasarkan tingkat pekerjaan baik sebanyak 36 orang $(70,6 \%)$ bekerja dan 21 orang $(53,8 \%)$ tidak bekerja. Sikap orang tua dalam pencegahan difteri baik sebanyak 75 orang $(83,3 \%)$, kurang baik sebanyak 11 orang $(12,2 \%)$ dan tidak baik sebanyak 4 orang $(4,4 \%)$. Hasil penelitian ini diharapkan dapat menjadi bahan pertimbangan kepada orang tua dalam menghindari penularan penyakit dengan cara senantiasa mencari informasi mengenai pencegahan difteri baik dari pelayanan kesehatan maupun media massa dan mengenali tanda dan gejala penyakit difteri.

Berdasarkan penelitian Safitri (2019), Penyuluhan Tetang Pentingnya Imunisasi Pada Bayi Di Desa Pelawan Kecamatan Pelawan Kabupaten Sarolangun.

Imunisasi adalah suatu upaya untuk menimbulkan/meningkatkan kekebalan seseorang secara aktif terhadap suatu penyakit, sehingga bila suatu saat terpapar dengan penyakit tersebut tidak akan sakit atau hanya mengalami sakit ringan. Setiap tahun lebih dari 1,4 juta anak di dunia meninggal karena berbagai penyakit sebenarnya dapat dicegah dengan imunisasi.. 
Hasil penelitian setelah diberikan informasi tentang imunisasi tim melakukan postest hasilnya mengalami peningkatan $85 \%$ ibu mempu menjelaskan pengertian imunisasi, $80 \%$ ibu mampu menyebutkan tujuan imunisasi, $80 \%$ ibu mampu menguraikan penyakit yang dapat dicegah dengan imunisasi, $100 \%$ ibu mampu menyebutkan tempat mendapatkan imunisasi, $90 \%$ ibu mampu menyebutkan jadwal imunisasi, $85 \%$ ibu mampu menerangkan keadaan yang tidak memperbolehkan anak diimunisasi, dan $80 \%$ ibu mampu menerangkan keadaan yang muncul setelah imunisasi. Serta $100 \%$ ibu memiliki kesadaran membawa anaknya untuk mendapatkan imunisasi. Disarankan kepada instansi yang terkait lebih mengoptimalkan peran tenaga kesehatan dalam memberikan penyuluhan seraca rutin khusunya tentang imunisasi sehingga ibuibu balita lebih mengetahui dan mau membawa anaknya untuk mendapatkan imunisasi dasar secara lengkap.

Berdasarkan penelitian Dewi, dkk(2014), Hubungan Tingkat Pengetahuan Ibu Dengan Pemberian Imunisasi Dasar Lengkap Pada Bayi Di Kelurahan Perupuk Tabing Wilayah Kerja Puskesmas Lubuk Buaya Kota Padang.

Alasan bayi tidak mendapatkan imunisasi lengap adalah karena alasan informasi, motivasi dan situasi. Alasan informasi berupa kurangnya pengetahuan ibu tentang kebutuhan, kelengkapan dan jadwal imunisasi, ketakutan akan imunisasi dan adanya persepsi salah yang beredar dimasyarakat tentang imunisasi. Alasan motivasi berupa penundaan imunisasi, kurangnya kepercayaan tentang manfaat imunisasi dan adanya rumor yang buruk tentang imunisasi. Alasan situasi berupa tempat pelayanan imunisasi yang terlalu jauh, jadwal pemberian imunisasi yang tidak tepat, ketidakhadiran petugas imunisasi, kurangnya vaksin, orangtua yang terlalu sibuk, adanya masalah dengan keluarga, anak yang sakit, terlalu lama menunggu dan biaya yang tidak terjagkau. Namun yang paling berpengaruh adalah karena anak sakit, ketidaktahuan waktu yang tepat untuk mendapatkan imunisasi berikutnya dan ketakutan akan efek samping imunisasi. Data ini menunjukkan bahwa pengetahuan sangat penting dalam pemberian imunisasi pada bayi. Jenis penelitian ini adalah analitik dengan cross sectional. Penelitian dilakukan pada ibu. Sampel pada penelitian ini adalah ibu yang memiliki bayi usia 1-2 tahun dan instrumen penelitian menggunakan kuesioner. Hasil penelitian diketahui bahwa persentas epemberian imunisasi dasar lengkap lebih banyak pada ibu dengan pengetahuan cukup $(87,5 \%)$ dibandingkan dengan pengetahuan kurang (4,3\%). Berdasarkan ujistatistik didapatkan adanya hubungan yang signifikan antara pengetahuan ibu dengan imunisasi dasar lengkap pada bayi dengan nilaip $<0,05$ danOdds Ratio $(\mathrm{OR})=154$ yang artinya ibu dengan pengetahuan cukupmemilikipeluang 154 kali untuk memberikan imunisasi dasar lengkap pada bayinya.

Berdasarkan penelitian Azizah, dkk (2011) Hubungan Tingkat Pengetahuan Ibu Tentang Pentingnya Imunisasi Dasar Dengan Kepatuhan Melaksanakan Imunisasi Di BPS Hj. Umi Salamah Di Desa Kauman, Peterongan, Jombang.

Kurang informasi yang diperoleh oleh masyarakat baik melalui media massa, media elektronik maupun penyuluhanpenyuluhan. Desain penelitian yang digunakan dalam penelitian ini adalah penelitian analitik dengan jenis pendekatan cross sectional, pengumupal data menggunakan data primer yang diperoleh dari kuesioner dan data sekunder dari observasi buku KMS. Data yang terkumpul diuji mann whitney dengan kemaknaan $\alpha$ $=0,05$. Hasil penelitian hampir seluruhnya ibu $17 \mathrm{ibu}(74 \%)$ memiliki pengetahuan baik sebagian besar 14 bayi (60\%) dengan imunisasi patuh. Untuk kepatuhan diperoleh hampir seluruhnya 17 orang ibu didapatkan hasil $\alpha=0,008$ berarti $\alpha<0,05$, sehingga dapat disimpulkan bahwa ada hubungan tingkat pengetahuan ibu tentang pentingnya 
imunisasi dasar dengan kepatuhan melaksanakan imunisasi.

Berdasarkan penelitian Azzahra dan Muniro (2015) Pengaruh Konseling Terhadap Pengetahuan Dan Sikap Pemberian MP-ASI Di Wilayah Kerja Puskesmas Brambang Kabupaten Jombang.

Konseling merupakan pendekatan komunikasi interpersonal yang sering digunakan dalam peningkatan pengetahuan dan perubahan sikap serta prilaku dalam bidang konseling, konseling menumbuhkan kerjasama dan komunikasi yang baik antar konselor sehingga menciptakan suasana yang nyaman. Responden sebanyak 12 orang, ibu pada kelompok kontroldiberikan leaflet pada kelompok perlakuan diberi leaflet dan konseling. Pemberian konseling dilakukan satu kali setiap bulan selama 1520 menit selama tiga bulan. Hasil penelitian ini menunjukkan bahwa terdapat perbedaan tingkat penegtahuan baik pada kelompok perlakuan $(\mathrm{p}=0,005)$ maupun kelompok kontrol.

\section{SIMPULAN}

Bedasarkan analisis dari beberapa sumber buku menjelaskan bahwa imunisasi DPT adalahsuatu vaksin yang melindungi terhadap difteri, pertusis dan tetanus. Difteri desebabkan bakteri yang menyerang tenggorokan dan dapat menyebabkan komplikasi yang serius dan fatal. Penyakit ini mudah menular melalui batuk atau bersin. Pertusis (batuk rejan) adalah infeksi bakteri pada saluran udara yang ditandai dengan batuk hebat yang menetap serta bunyi pernafasan yang melengking. Pertusis juga dapat menimbulkan komplikasi serius, seperti pneumonia, kejang dan kerusakan otak. Tetanus adalah infeksi bakteri yang bisa menyebabkan kekakuan pada rahang serta kejang. Vaksin ini diberi 5 kali pada usia 2,4,6,18 bulan dan 5 tahun. Mastiningsih (2018) menyebutkan bahwa Beberapa reaksi lokal sementara seperti bengkak, nyeri dan kemerahan pada lokasi suntikan disertai demam dapat timbul dalam sejumlah besar kasus. Kadang-kadang reaksi berat seperti demam tinggi, irritabilitas (rewel), dan menangis dengan nada tinggi dapat terjadi dalam 24 jam setelah pemberian. Episode hypotonichyporesponsive pernah dilaporkan. Kejang demam telah dilaporkan dengan angka kejadian 1 kasus per 12.500 dosis pemberian. Pemberian asetaminofen pada saat dan 4-8 jam setelah imunisasi mengurangi terjadinya demam.

\section{SARAN}

- Bagi Stikes Mitra Adiguna Palembang

Diharapkan dapat lebih menfasislitasi (misalnya memperbanyak referensi atau literatur yng berkaitan dengan penelitian) dan memberi kemudahan kepada mahasiswa untuk melakukan penelitian demi perkembangan ilmu pengetahuan serta penelitian ini dapat menjadi konstribusi tambahan berupa informasi, pengetahuan dan pemahaman lebih berupa sumbangan fikiran melalui metode pendidikan sebagai bahan referensi guna pengembangan ilmu pengetahuan khususnya kebidanan.

- Bagi Penelitian Selanjutnya

Diharapkan hasil penelitian ini sebagai acuan bagi peneliti sendiri dan peneliti selanjutnya agar dapat melanjutkan penelitian berikutnya dengan metode yang berbeda khususnya dilingkup kebidanan.

\section{DAFTAR PUSTAKA}

Aprilia, Riska, dkk. Hubungan Pengetahuan Dengan Sikap Ibu Tentang Imunisasi Difteri Pada Anak Balita Di Desa Jatiwates Kecamatan Tembelang Kabupaten Jombang. Jurnal Keperawatan. 2018.

Atika PD, Eryati D, Edison. Hubungan Tingkat Pengetahuan Ibu Dengan Pemberian Imunisasi Dasar Lengkap Pada Bayi di Kelurahan Parupuk Tabing Wilayah Kerja Puskesmas Lubuk Buaya Kota Padang Tahun 2013. JKA. 2014. 
Azzahra, Margareta Fatimah dan Lailatul Muniroh. Pengaruh Konseling Terhadap Pengetahuan Dan Sikap Pemberian MP-ASI. Media Gizi Indonesia. 2015.

Darmadi, Hamid. 2011. Metode Penelitian Pendidikan. Bandung : Alfabeta.

Dewi, Vivian Nanny Lia. 2017. Asuhan Neonatus Bayi dan Anak Balita. Jakarta: Salemba Medika.

Global and Regional Immunization Profile. 2018. Percentage of target population vaccinated. UNICEF.

Gusti, Dalina. Pengaruh Promosi KEsehatan Menggunakan Metode Konseling Terhadap Peningkatan Pengetahuan Ibu Hamil Tentang Imunisasi Dasar Anak Di Wilayah Kerja Puskesmas Nanggalo Padang. Menara Ilmu. 2017.

Hadianti, Dian Nur, dkk. 2014. Buku Ajar Imunisasi. Jakarta: Kementerian Kesehatan RI.

Ike AY, Devi K, Oktarina. Hubungan Pengetahuan Ibu Tentang Efek Samping Imunisasi DPT Combo Dengan Kejadian Demam Pada Bayi Usia 2-12 Bulan di BPS Yulianti Amd.keb KElurahan Talang TEluk Betung Selatan Bandar Lampung Tahun 2015. Jurnal Kebidanan. 2015.

Isnanianti FA dan Corie IP. Faktor Berhubungan Dengan Kasus Difteri Anak Di Puskesmas Bangkalan Tahun 2016. Jurnal Berkala Epidemiologi. 2017.

Kementerian Kesehatan RI. 2018. Cakupan Imunisasi Dasar Pada Bayi Menurut Provinsi. Jakarta.
Krisdiana W, Vina AA, Aulia F. 2016. Komunikasi Dalam Praktik Kebidanan. Jakarta: Trans Info Media.

Marimbi, Hanum. 2010. Tumbuh Kembang, Status Gizi, dan Imunisasi Dasar Pada Balita. Yogyakarta: Nuha Medika.

Mastiningsih, Putu. 2018. Buku Ajar Imunisasi Dasar. Bandung: In Media.

Melisa CK, Sefti R, Yolanda B. Hubungan Pemberian Imunisasi Dasar Dengan Tumbuh Kembang Pada BAyi (0-1 tahun) di Puskesmas Kembes Kecamatan Tombulu Kabupaten Minahasa. 2019. JAK. 2019.

Notoatmodjo, Soekidjo. 2010. Metodologi Penelitian Kesehatan. Jakarta: Rineka Cipta.

Profil Kesehatan RI. 2018. Data dan Informasi Profil Kesehatan Indonesia. Jakarta.

Risya RH, Tuhu P, Aryani P. Gambaran Pengetahuan dan Motivasi Ibu Tentang Pemberian Imunisasi DPT Lanjutan (Booster) Di Puskesmas Simpang IV Sipin Kota Jambi. JAK. 2019.

Rukiyah, Ai Yeyeh dan Lia Yulianti. 2012. Asuhan Neonatus Bayi dan Anak Balita. Jakarta: Trans Info Media.

Rustawan, Uus. 2019. Teknik Penulisan Tugas Akhir Dan Skripsi Pemrograman. Jakarta : PT Gramedia.

Safitri. Penyuluhan Tentang Pentingnya Imunisasi Pada Bayi Di Posyandu Kasih Ibu Di Desa Pelawan Kecamatan Pelawan Kabupaten Sarolangun. JAK. 2019.

Sekar PK. Gambaran Pengetahuan dan Sikap Orang tua Dalam Pencegahan Difteri Di Desa Walitelon Utara Temanggung. 2019. 
Siti HS, Fenti DP, Ichayuen A. Gambaran Pengetahuan Orangtua, Dukungan Keluarga, Dan Status Imunisasi Terhadap Kejadian Difteri Pada Balita Di Wilayah Puskesmas Cileungsi Kabupaten Bogor Tahun 2018. Jurnal Mahasiswa Kesehatan Masyarakat. 2019.

Sugiyono. 2016. Metode Penelitian Kombinasi. Bandung: Alfabeta.

Survei Demografi Dan Kesehatan. 2017. Cakupan Imunisasi Dasar Lengkap. Jakarta.

Yulifah, Rita dan Tri JAY. 2015. Komunikasi Dalam Praktik Kebidanan. Jakarta: Salemba Medika. 